BAPL, 40. 2005 (9-37)

\title{
EL QUIJOTE, ELOGIO DE LA LECTURA“
}

\author{
Eduardo Hopkins Rodríguez
}

\section{A mis padres $y$ hermanos \\ A Martha y a nuestros hijos}

Miguel de Cervantes expone en El Ingenioso hidalgo don Quijote de la Mancha la capacidad de las personas, locas y cuerdas, para crear a partir de la lectura. Es en este primer sentido su novela un elogio de la lectura y lo es, sobre todo, por haber construido un complejo discurso narrativo, cuyos personajes, tiempo, espacio y acciones no solamente están sustentados en el acto de leer, sino que son ellos mismos lectura.

En la España que muestra Cervantes en el mundo de El Quijote, todos los personajes leen o desean leer. Si pensamos en la realidad histórica de ese espacio cultural con su 80\% de analfabetos (Chevalier 1976: 19), este deseo puede resultar paradójico. Recordemos que el mismo Sancho es un

Texto leído el 17 de junio del año 2005, con motivo de la incorporación del autor como Miembro de Número de la Academia Peruana de la Lengua. 
analfabeto convicto y confeso $(256,316)$, aunque posee una experiencia literaria que irá incrementándose progresivamente. Roger Chartier ha observado cómo entre los siglos XIV y XVIII "lo escrito está instalado en el corazón mismo de la cultura de los analfabetos, presente en los ritos, en los espacios públicos, en los lugares de trabajo. Gracias a la palabra que lo descifra, gracias a la imagen que lo duplica, se ha vuelto accesible incluso para aquellos que son incapaces de leerlo y que no pueden tener, por sí mismos, más que una comprensión rudimentaria." (Chartier 2000: 37) Como no hay equivalencia entre analfabetismo e ignorancia, cabe preguntarse de qué manera se compensa el ansia de lectura que se aprecia en quienes no saben leer ni escribir en la novela de Cervantes. Obviamente, mediante formas orales de recepción. Sabemos que la práctica de la lectura en voz alta era parte del sistema pedagógico español desde la Edad Media. También era una costumbre que se asumía como forma social de lectura, la que se mantuvo en España hasta el siglo XVIII. (Frenk 1997: 10, 19) En una pieza teatral como La Celestina, el diálogo crea la escenografía y presenta el aspecto físico de los caracteres debido a que la recepción de la obra no se realizaba mediante la puesta en escena, sino a través de la lectura en voz alta destinada a un reducido auditorio. Maxime Chevalier ha constatado la persistencia de "la costumbre de contar novelas en las tertulias españolas" y ha resaltado la importancia de la cultura oral en el siglo XVI. (Chevalier 1976: 46, 61) Hay noticias de que el emperador Carlos V "mandaba que le leyeran novelas de caballerías" y de que la emperatriz también era aficionada a escuchar este tipo de lecturas. (Chevalier 1976: 75-76) Margit Frenk sostiene que "dada la importancia que la voz seguía teniendo en la transmisión de los textos, el público de la literatura escrita no se limitaba a sus lectores, en el sentido moderno de la palabra, sino que pudo haberse extendido a un elevado número de oyentes, de todos los estratos sociales, incluyendo a la población analfabeta." (Frenk 1997: 25)

La norma generalizada de la audición de textos ha dejado huellas incluso en los textos escritos: "en los siglos XVI 
y XVII, a menudo la lectura implícita del texto, literario o no, está aún construida como una oralización, y su "lector" como el oyente de una palabra leída. Así, dirigida tanto al oído como al ojo, la obra juega con formas y procedimientos aptos para someter lo escrito a las exigencias propias de la "performance" oral". (Chartier 2000: 29)

La relación entre don Quijote y Sancho ilustra con plenitud el funcionamiento de la recepción oral de la literatura. Pese a los equívocos de su receptor principal, don Quijote logra comunicar a Sancho una buen parte de sus lecturas. Frenk llama la atención hacia ciertas declaraciones en el texto de El Quijote, como el final de II: 25: "comenzó a decir lo que oirá y verá el que le oyere o viere el capítulo siguiente" y el epígrafe de II: 66: "Que trata de lo que verá el que lo leyere o lo oirá el que lo escuchare leer". (Frenk 1997: 28)

Es fácil constatar que en El Quijote la lectura no solamente es visual, sino que corresponde también al plano de la audición. Si la idea de que hay "magia" en los libros circula ampliamente en la obra, es porque se reconoce que los libros tienen poder. En parte, se trata de un poder persuasivo que se ejerce a través de la argumentación. Pero, mayoritariamente, la lectura tiene el poder de provocar la realización pragmática de sus temas y formas directamente en la realidad. La pastora Marcela no persuade a nadie de su entorno acerca de sus justas razones para vivir sin pareja. En cambio, todos quieren vestirse como pastores y dedicarse a la vida pastoril como ella.

La lectura produce arquetipos de conducta que son asumidos por los personajes de Cervantes, dando lugar a variaciones en sus acciones y discursos. Es frecuente en la sociedad española de la época acudir a situaciones y figuras de la literatura como una forma de enfrentar problemas reales. La literatura española es rica en personajes que se contemplan a sí mismos desde modelos literarios. En La Celestina, por ejemplo, que sigue metódicamente un patrón de transgresiones 
a las reglas literarias del amor cortés, tanto Calisto como Melibea interpretan sus experiencias amorosas desde múltiples transposiciones literarias. Calisto adopta actitudes típicas de personaje de poemas de amor cortés o de novela sentimental, mientras que Melibea se ve como el sujeto lírico de aventureros romances moriscos, de tiernas albadas y de dolorosos poemas de mal maridada. En la lectura es cuando la tradición se recrea, se ratifica, se confronta y relativiza. Bajo tal perspectiva es que se puede entender un lamento de Melibea como el siguiente: "si passar quisiere la mar, con él yré; si rodear el mundo, lléveme consigo; si venderme en tierra de enemigos, no rehuyré su querer [...] que más vale ser buena amiga que mala casada". (Rojas 1991: 535; Cfr. Lida 1962: 322)

Don Quijote "lee" la realidad a través de sus lecturas, de tal manera que el arquetipo, el modelo leído, regula su interpretación de la realidad. Félix Martínez Bonati explica que el fenómeno de la lectura problematiza en El Quijote el sentido de la realidad. (Martínez 1995) Al mismo tiempo, y como parte de esta problemática, el sentido de la realidad queda intensamente actualizado, lo cual, de acuerdo con Martínez Bonati, constituye uno de los significados particulares de la obra. (Martínez 1995: 247) Personalmente, me inclino hacia la idea de que Cervantes postula un enriquecimiento de la realidad por la vía de la imaginación alimentada desde la literatura. Para Cervantes la realidad es prosaica, informe y carente de estilo, por eso los hombres necesitan de la literatura para otorgarle una dimensión artística y un perfil estilizado. Después de todo, como confiesa Cervantes, El Quijote se "engendró en una cárcel, donde toda incomodidad tiene su asiento y donde todo triste ruido hace su habitación" (Prólogo, 7) La cárcel es la platónica metáfora del mundo real que el escritor preferiría ver transformado en un espacio caracterizado por "el sosiego, el lugar apacible, la amenidad de los campos, la serenidad de los cielos, el murmurar de las fuentes, la quietud del espíritu". (Prólogo, 7) Es claro que esta deseada materialización de una realidad amable no es más que una transferencia del paisaje literario arcádico. 
Según Américo Castro, "el Quijote debe su existencia tanto a una tradición de formas y géneros literarios como a una tradición de maneras de ser vivida la literatura" (Castro 1967: 372) Como a todos los personajes de la novela les afecta en mayor o menor grado la lectura, Castro define la particular relación de la obra con su recepción: "Los libros aparecen aquí como motivación de la vivencia valorativa de quienes, en virtud de ella se hacen existentes". (Castro 1967: 373) Por tal razón, continúa Américo Castro, "el libro se incorpora a la experiencia vital de cada uno", es un correlato "de las vivencias de cada lector". Es así como la literatura se personaliza y la vida individual puede alcanzar sus "posibilidades poéticas" (Castro 1967: 373)

Propone Castro que uno de los efectos de esta manera de asumir la literatura consiste en que "el contenido del libro se multiplica por la experiencia de los afectados por él, o rebota sobre ella". (Castro 1967: 374) El supuesto esencial de este fenómeno radica en que la palabra escrita es sentida como "realidad de alguien, vitalizada, y no como simple expresión de fantasías o conocimientos distanciados del lector". Motivo por el cual en El Quijote los libros participan por "su vitalidad contagiosa, y no por ser depósitos de cultura”. (Castro 1967: 374) Castro encuentra que en la tradición oriental el sentido de la palabra como "contenido y transmisor de una revelación" permite "sentir los libros como realidad viva, animada, comunicada e incitante". (Castro 1967: 376) Y dado que la presencia oriental en el mundo español dejó, entre otros, el legado del "tema de la lectura de los libros, como fuente de bienes y de males", las obras literarias manifiestan una marcada tendencia a detectar el efecto que produce la experiencia de la lectura en las personas. (Castro 1967: 378) Cuando el Cura cuenta al Oidor la historia del Cautivo, éste observa atentamente las reacciones de su hermano. Efectivamente, podemos constatar que El Quijote es una suerte de tratado concerniente a los efectos que la lectura puede generar y genera en el receptor. 
Es típica la influencia del gusto de los lectores en el proceso de la producción literaria del Siglo de Oro español, contribuyendo en la reorientación de los proyectos autoriales. Baste mencionar casos tan notables como los de La Celestina y La Araucana. Este es un aspecto que aparece claramente diseñado en la Segunda parte de El Quijote, cuando los personajes lectores de la Primera Parte intervienen en la acción motivados por su lectura. Igualmente, los lectores, reales o empíricos, con sus opiniones obligan al autor a variar su método narrativo. Cervantes, en apariencia cede a estas presiones, cuando en verdad lo que hace es intensificar radicalmente su sistema narrativo digresivo, aunque lo hace de manera encubierta.

Los criterios morales del periodo en torno a la lectura insisten en promover obras de valor edificante: "todos los discursos sobre el libro y la lectura muestran una particular inquietud por los volúmenes etiquetados de "deshonestos, profanos o de caballerías", es decir, por cuantos se escaparan de los cauces de la ortodoxia o se adentraran por los territorios de la imaginación, vistos como indecorosos para la seriedad de aquella sociedad. De modo que si algo se atisba en todas las disquisiciones librescas, incluso más que la vigilancia ortodoxa, es la concepción exclusivamente utilitarista de la lectura". (Castillo 2003: 127-128)

Carlos Fuentes ve la novela de Cervantes como una crítica de la lectura unívoca y dogmática, a la que se opone la lectura plural. (Fuentes 1976: 19 y ss.) Sin embargo, más que plantear autónomamente este punto de vista, Cervantes observa que frente a las funciones cívicas y morales que las instituciones sociales buscan asignar a la literatura, las personas asumen la lectura de obras literarias bajo principios más espontáneos y libres. El criterio de los moralistas está preocupado por las significaciones de las obras y su influjo en la conducta de las personas. En cambio, los personajes lectores en El Quijote, incluso aquellos que postulan una teoría clásica y ejemplarizante del arte como el Cura y el Canónigo, asumen 
la literatura como un instrumento que impulsa la dinámica productiva de la imaginación individual y colectiva. Para estos, la significación radica en el efecto sobre la vivencia personal, en las actitudes humanas como portadoras de valores, en el juego emocional desplegado en las obras y, muy especialmente, en la capacidad para enriquecer imaginativamente la vida cotidiana y conducirla hacia rangos intensos de realización personal. Pese a que Cervantes declara explícitamente estar de parte de una concepción edificante de la literatura, su obra propone el principio estético como el dominante en su visión de la novela, con lo cual coincide con la manera de disfrutar la literatura adoptada por un gran sector de sus personajes.

Las elucidaciones de Cervantes relativas a la lectura la muestran como alimento de la imaginación y como medio para darle forma a la vida de acuerdo con principios que pertenecen más al campo de la experiencia humana intemporal y general que a la visión moralizante humanista y cristiana. Lo que le interesa a Cervantes es el escrutinio de las diversas formas de reaccionar de los lectores frente a los textos orales o escritos. En El Quijote leer se vuelve actividad lúdica, momento de compensación, apertura hacia lo universal, estímulo para la acción y para la auto representación. Lo que importa es la productividad discursiva y su capacidad de generar nuevos discursos imaginativos y nuevos ejercicios existenciales. La lectura no es solamente una actividad mental, sino que corresponde a un accionar concreto. En este sentido activo, si los discursos se vuelcan hacia la práctica vital y social, es por su potencialidad constructiva, no por su valor moral. El autor lo señala con lucidez en la Segunda Parte, en el discurso que atribuye a Cide Hamete acerca de su gusto por las digresiones y su solicitud de que se preste atención a los relatos intercalados como las novelas del Curioso Impertinente y la del Capitán Cautivo de la Primera Parte: “También pensó, como él dice, que muchos llevados de la atención que piden las hazañas de don Quijote, no la darían a las novelas, y pasarían por ellas, o con priesa, o con enfado, sin advertir la gala y artificio que en sí contienen, el cual se 
mostrara bien al descubierto cuando por sí solas, sin arrimarse a las locuras de don Quijote ni a las sandeces de Sancho, salieran a luz; y así, en esta segunda parte no quiso injerir novelas sueltas ni pegadizas, sino algunos episodios que lo pareciesen, nacidos de los mesmos sucesos que la verdad ofrece, y aun estos limitadamente y con solas las palabras que bastan a declararlos; y pues se contiene y cierra en los estrechos límites de la narración, teniendo habilidad, suficiencia y entendimiento para tratar del universo todo, pide no se desprecie su trabajo, y se le den alabanzas no por lo que escribe, sino por lo que ha dejado de escribir". (877-878) En el capítulo XXVIII de la Primera Parte ya se aludía positivamente a las digresiones incluidas en la obra: "Felicísimos y venturosos fueron los tiempos donde se echó al mundo el audacísimo caballero don Quijote de la Mancha, pues por haber tenido tan honrosa determinación como fue el querer resucitar y volver al mundo la ya perdida y casi muerta orden de la andante caballería, gozamos ahora en esta nuestra edad, necesitada de alegres entretenimientos, no solo de la dulzura de su verdadera historia, sino de los cuentos y episodios de ella, que, en parte, no son menos agradables y artificiosos y verdaderos que la misma historia". (274) Cuando Cardenio cuenta su historia al Cura y al barbero, establece pautas de lectura específicas respecto a las digresiones en que incurre: "No os canséis, señores, de oír estas digresiones que hago; que no es mi pena de aquellas que puedan ni deban contarse sucintamente y de paso, pues cada circunstancia suya me parece a mí que es digna de un largo discurso". (269). El Cura responde defendiendo las digresiones especificando que "no sólo no se cansaban de oírle, sino que les daba mucho gusto las menudencias que contaba, por ser tales, que merecían no pasarse en silencio, y la mesma atención que lo principal del cuento". (269)

Si bien, en palabras del narrador, la Segunda Parte se pretende menos digresiva que la primera, la verdad es que en términos de invención narrativa continúa con mayor energía que antes, aunque envolviendo los relatos bajo motivaciones 
concentradas en la acción central. Esta es la respuesta que se da a las críticas de los lectores de la Primera Parte, resumidas por Sansón Carrasco en el Capítulo III de la Segunda Parte, en las que se aludía particularmente a El curioso impertinente y su falta de justificación con respecto a la historia principal. Por nuestro lado, consideramos que la presencia de este relato se justifica por el tópico de la productividad de la lectura para la representación mimética en el universo de los lectores; por la capacidad ilusionista de la ficción sobre el receptor y por mostrar una variable extrema de la temática de búsqueda obsesiva de la prueba de fidelidad en el amor.

La lectura como actividad de libre elección, comprensión y goce, queda expuesta por el Bachiller Sansón Carrasco cuando deslinda las reacciones de los diferentes lectores de la narración acerca de don Quijote y Sancho: "hay diferentes opiniones como hay diferentes gustos: unos se atienen a la aventura de los molinos de viento, que a vuestra merced le parecieron Briareos y gigantes; otros, a la de los batanes; este, a la descripción de los dos ejércitos, que después parecieron ser dos manadas de carneros; aquel encarece la del muerto que llevaban a enterrar a Segovia; uno dice que a todas se aventaja la de la libertad de los galeotes; otro, que ninguna iguala a la de los dos gigantes benitos, con la pendencia del valeroso vizcaíno". (1009-1010) Como puede observarse, entre los comentarios de lectores no aparece el factor moralizante integrando sus juicios de valor. Además, hay en el citado pasaje la idea de que el significado de un texto no es algo fijo, sino que su estipulación depende de cada receptor. El carácter impredecible de las reacciones de los receptores es otro aspecto involucrado en este comentario. Una posición similar la encontramos en la Primera Parte, en las intervenciones del ventero, su hija y Maritornes, tocantes a lo que cada cual ve, según su sensibilidad e intereses, en los libros de caballerías. Martínez Bonati resalta cómo en la novela de Cervantes el texto escrito "puede ser leído, releído, examinado, discutido". (Martínez 1995: 249) Es lo que explica Sansón Carrasco a don Quijote y a Sancho: "las obras impresas se miran despacio, 
fácilmente se ven sus faltas, y tanto más se escudriñan cuanto es mayor la fama del que las compuso". (573) Esto es posible por ser la lectura analítica apropiada a la escritura. Sin embargo, en El Quijote ante la recepción oral de los relatos, discursos y poemas los oyentes realizan observaciones analíticas de gran precisión, como si estuvieran ante textos escritos. Es exactamente el mismo fenómeno que uno aprecia en el teatro español del Siglo de Oro, cuya elaborada técnica de escritura exige que los actores ejecuten las obras en escena con tal virtuosismo en la dicción que puedan lograr que el auditorio capte las sutilezas conceptuales, métricas y estróficas del diálogo. Además, dadas las intensas funciones deícticas del texto dramático del Siglo de Oro, para este público, oír es como ver, motivo por el cual era indispensable para ver el espectáculo captar auditivamente todo detalle del diálogo. Lo que podríamos denominar competencia literaria, aunque es un componente teórico discutido en la obra como algo exclusivo de gente educada y negado a la mayoría de las personas, en la práctica no es un factor importante, pues todos los personajes letrados o analfabetos están en disposición de participar con eficiencia en la lectura directa o indirecta, escrita u oral.

Entre las funciones que ejerce la lectura en la novela reconocemos las de dar lugar al conocimiento, al placer estético, la polémica social, la expresión de opiniones, la comunicación intersubjetiva, la mimesis. Esta última, en tanto influjo en la praxis vital, como ejemplo, como modelo, como arquetipo, como identificación entre ficción y realidad, entre lector y ficción, entre miembros del grupo. La función mimética de la lectura es fundamental en la acción de la novela. Gracias a ella se pone en escena numerosas situaciones ficticias basadas en referencias literarias. También posee cualidades significativas múltiples. Entre las significaciones posibles de la lectura en su función mimética encontramos una que es de la mayor envergadura, consistente en la connotada por la voluntad siempre dispuesta para trasladar la ficción de los textos hacia la realidad procediendo a la respectiva ficcionalización de esta. La imitación de Amadis, adoptado como el modelo de 
perfección de la caballería, junto a la de otros caballeros de novela, es un ejemplo de combinación de lecturas y prácticas miméticas:

"¿Ya no te he dicho -respondió don Quijote- que quiero imitar a Amadís, haciendo aquí del desesperado, del sandio y del furioso, por imitar juntamente al valiente don Roldán, cuando halló en una fuente las señales de que Angélica la Bella había cometido vileza con Medoro, de cuya pesadumbre se volvió loco, y arrancó los árboles, enturbió las aguas de las claras fuentes, mató pastores, destruyó ganados, abrasó chozas, derribó casas, arrastró yeguas e hizo otras cien mil insolencias, dignas de eterno nombre y escritura? Y puesto que yo no pienso imitar a Roldán [...] parte por parte, en todas las locuras que hizo, dijo y pensó, haré el bosquejo, como mejor pudiere, en las que me pareciere ser más esenciales. Y podrá ser que viniese a contentarme con sola la imitación de Amadís, que sin hacer locuras de daño, sino de lloros y sentimientos, alcanzó tanta fama como el que más". (235-236)

Esta capacidad de elección es ratificada cuando decide quitarse las armas "y quedar desnudo como cuando nací, si es que me da en voluntad de seguir en mi penitencia más a Roldán que a Amadís". (237) Don Quijote se muestra libre de elegir entre partículas de modelos preferidos para construir una versión apropiada a sí mismo, una "tan rara, tan felice y tan no vista imitación" (236), cuya singularidad espera que sea consignada textualmente en la memoria de Sancho para ser contada a Dulcinea:

“!Oh tú, escudero mío, agradable compañero en mis prósperos y adversos sucesos, toma bien en la memoria lo que aquí me verás hacer, para que lo cuentes y recites a la causa total de todo ello!" (238)

Es así como la mimesis de la lectura da lugar a la producción de una nueva escritura. 
Un segundo tipo importante de significación de la funcionalidad mimética de la lectura se deriva del transporte de lo vivido hacia la ejecución de actos ficticios, como sucede con Dorotea en su interpretación del papel de la desvalida princesa Micomicona, actuación nutrida por referentes librescos y por los sucesos que ha padecido en su accidentada relación con don Fernando. Precisamente, su invención del gigante que la amenaza es como una proyección de las negativas acciones pasadas de Fernando, así como su caracterización como mujer noble realiza en el terreno de lo ficticio la superación de una carencia social que la apartaba de su pareja. Dorotea ritualiza su angustia en el acto de representación, el que es una suerte de segundo relato de su vida sentimental transfigurado literariamente por la lectura de novelas. Sancho revierte las figuras y nos permite aclarar estas relaciones proyectivas: "la linda princesa Micomicona se le había vuelto en Dorotea, y el gigante en don Fernando". (384)

En El Quijote el concepto de productividad de la lectura significa que la lectura genera escritura: por diferencia, por semejanza, por reproducción. La imaginación de los lectores en la novela de Cervantes queda capturada por sus lecturas. Para Cervantes la capacidad de la imaginativa es universal e innata. Solamente basta con provocarla para desencadenar plenamente su actividad.

Uno de tales tipos de productividad lectora consiste en la parodia y la auto parodia, ambas formas narrativas sustanciales en El Quijote. Parte esencial de su núcleo paródico concierne tanto a las novelas de caballería como a las novelas pastoriles, la épica, el teatro y la poesía lírica. La parodia es un tipo de lectura deformadora, seria, burlesca o satírica, que es al mismo tiempo una forma de reescritura. Supone una lectura profunda y su respectiva inversión creativa. Pero la escritura paródica solamente es legible desde un horizonte de lecturas comunes, dentro del cual el escritor y su lector pueden desplazarse con soltura y satisfacción. El 
placer que produce la parodia concierne a la satisfacción de compartir un conocimiento y una experiencia. En el fondo, la parodia es un elogio de sí mismo, autor y receptor, que implica un elogio de la lectura como espacio de iniciados y de expertos. El Quijote no solamente es parodia de cierta clase de libros, sino que es, sobre todo, una gran parodia del libro, con textos preliminares y poemas de homenaje inventados, con fuentes inexistentes, con lectores que parasitan tanto la escritura como la lectura, con pseudo epílogos, etc. Consecuentemente, es una magnífica parodia de la lectura, mediante la cual Cervantes se burla de las maneras en que mujeres y varones pervierten o revierten la lectura.

El Quijote asume radicalmente la celebración del principio paródico de que la literatura es una cita de textos previos, lo que significa una cancelación de la autoreferencialidad de la obra particular para enlazarla con la red literaria y discursiva de su época, produciendo una condición de autoreferencialidad artística general de índole superior a la individual. (Hutcheon 2000: 1-2) Sin embargo, el sentido de parodia excede en Cervantes el campo de las relaciones con la red literaria para dar lugar al espectáculo de las modalidades en que la vida parodia a la literatura. Esto se aplica tanto al personaje don Quijote como a los personajes lectores en su libro. Por eso tenemos parodias internas, como el efecto que produce en sus oyentes la presencia y el discurso, ya paródicos, de don Quijote; las parodias de la Primera Parte en la Segunda; las parodias de lo apócrifo, como en el duque y su mujer, personajes que actúan como "autores" de la segunda parte, y que con su afán de inventar ficciones quijotescas parodian a Avellaneda, autor de un Quijote apócrifo; la historia de Leandra, en tanto parodia de la historia de la pastora Marcela, la cual, por su lado, es una parodia de casos de novela pastoril. Dorotea, al participar en el plan del Cura y el Barbero para recuperar a don Quijote fingiendo ser princesa en busca de un favor suyo, aplica el estilo literario típico de las mujeres desvalidas que ha aprendido gracias a sus numerosas lecturas de libros de caballerías. Toda la escena de su entrevista con 
el caballero está moldeada desde la lectura. Para quienes participan del engaño, constituye una forma de lectura observar cómo se desempeñan sus compañeros en el juego. Así ocurre con Cardenio y el Barbero "deseosos de ver cómo fingía su historia la discreta Dorotea". (302) Lo que se elogia en la realización del engaño es, como dice el Cura, la precisa correspondencia de "estilo y modo" (309) entre la escena y el modelo literario. Estamos ante un caso más en que las acciones de los personajes son una intencional parodia literaria, al mismo tiempo que un traslado de la letra a la realidad. Desde una tonalidad humorística, Maritornes y la hija del ventero, aplican lo aprendido como oyentes de libros de caballerías engañando al hidalgo para dejarlo sobre Rocinante atado de la muñeca a través de una ventana. (452-453) En la "Novela del curioso impertinente", que se lee en voz alta ante un grupo numeroso (327), las citas y lecturas de poemas y textos en prosa abundan como parte de la argumentación verbal de sus personajes. También, como en la acción central de la novela, en el relato del curioso impertinente se hace uso de complejas y extensas actuaciones fingidas cargadas de materia literaria inyectada en la actividad de los sujetos. (357 y ss.) La escena trágica que desde su escondite ve Anselmo de su esposa Camila junto a Lotario y la criada es una representación dramática elaborada por Camila para engañarlo de acuerdo con calcos y pastiches literarios: "Atentísimo había estado Anselmo a escuchar y a ver representar la tragedia de la muerte de su honra, la cual con tan extraños y eficaces afectos la representaron los personajes de ella, que pareció que se habían transformado en la misma verdad de lo que fingían". (365) Las referencias a Penélope, Lucrecia y Porcia, nos dan la pista de los modelos que sirven de guía a Camila para mostrarse como un "simulacro de la honestidad" (364). Es notable la amplitud de lecturas de que da muestras Camila en su múltiple papel como autora, directora y actriz del espectáculo que ofrece a su marido. Ella, como don Quijote, también se imagina, en el discurso de su patraña dramática, hipotéticamente proyectada en forma textual: "sepa el mundo, si acaso llegare a saberlo, de que Camila no solo guardó la 
lealtad a su esposo, sino que le dio venganza del que se atrevió a ofenderle". (360) El engañado Anselmo participa, irónicamente, del deseo de textualización de Camila: "quería que no fuesen otros sus entretenimientos que en hacer versos en alabanzas de Camila que la hiciesen eterna en la memoria de los siglos venideros". Ironía sobre ironía, la promesa de textualidad se extiende hasta Lotario, amante de Camila, quien "alabó su buena determinación y dijo que él, por su parte, ayudaría a levantar tan ilustre edificio". (365)

Es interesante la idea de Steven Hutchinson (1992: 24) acerca de la presencia de la antigua metáfora de la lectura como viaje en EI Quijote, en la cual el valor de significado reside en el hecho de viajar, y que aplicada a la novela de Cervantes consideramos que implica tanto una transposición del tema del caballero andante a los distintos instantes de lectura durante la acción de la obra, como una transposición del proceso de lectura a la trayectoria del personaje. Bajo esta última perspectiva, lo que hace don Quijote durante su caminar es pasar de una lectura a otra. A veces lee novelas de caballería, en otras ocasiones su lectura es la de la pastoral narrativa.

La dependencia del texto respecto al lector y sus alcances, postulada por la novela de Cervantes, podemos distinguirla en la discusión entablada entre el Cura y el ventero:

"Y como el cura dijese que los libros de caballerías que don Quijote había leído le habían vuelto el juicio, dijo el ventero:

-No sé yo cómo puede ser eso, que en verdad que, a lo que yo entiendo, no hay mejor letrado en el mundo, y que tengo ahí dos o tres de ellos, con otros papeles, que verdaderamente me han dado la vida, no solo a mí, sino a otros muchos. Porque cuando es tiempo de la siega, se recogen aquí las fiestas muchos segadores, y siempre hay alguno que sabe leer, el cual coge uno de estos libros en las manos, y rodeámonos de él más de treinta, y estámosle escuchando con tanto gusto, que nos quita mil canas. A lo menos, de mí sé decir que 
cuando oyo decir aquellos furibundos y terribles golpes que los caballeros pegan, que me toma gana de hacer otro tanto y que querría estar oyéndolos noches y días". (321)

Esta es la expresión de su personal comprensión y gusto alrededor de la lectura auditiva de libros de caballerías. Volverse "loco de placer" (324) es frase del ventero que sintetiza su respuesta en torno a la audición de dichos textos y que remeda en cierta medida lo acontecido a don Quijote.

Maritornes y la hija del ventero, manifiestan igualmente su propia reacción y disfrute ante las lecturas que escuchan de los aludidos libros. La primera, es una receptora sensual, quien dice gustar "mucho de oír aquellas cosas, que son muy lindas, y más cuando cuentan que se está la otra señora debajo de unos naranjos abrazada con su caballero, y que les está una dueña haciéndoles la guarda, muerta de envidia y con mucho sobresalto. Digo que todo esto es cosa de mieles". (321) La hija del ventero, en cambio, es una receptora sentimental, que declara disfrutar "de las lamentaciones que los caballeros hacen cuando están ausentes de sus señoras, que en verdad que algunas veces me hacen llorar, de compasión que les tengo". (322)

En la metodología de la retórica clásica la memoria es un método para la invención y la ejecución oratoria que sirve para ordenar sistemáticamente por asociación espacial y mediante imágenes los componentes del discurso. Este mecanismo en sus dos funciones inventiva y mnemotécnica aparece en El Quijote cuando seres, imágenes y espacios reales provocan su memoria de lecturas gracias a la cual son transfigurados en entidades nuevas modalizadas como tópicos nuevos. Tal procedimiento es puesto en acción de manera consciente por diversos personajes cuando ver y oír a don Quijote funcionan como espacios e imágenes que los estimulan en su memoria de lecturas literarias para decidir inventar y construir de manera consciente nuevos espacios ficticios en los cuales envolver a don Quijote y a Sancho. 
La Arcadia constituye el motivo de una de las más impresionantes formas de traslación de lectura hacia la realidad en la vida y en la literatura de Europa durante los siglos XVI al XVIIl. Vivir la "pastoral Arcadia" (1061) es una vocación amada en la obra de Cervantes, quien escribió la primera parte de La Galatea (1585), una novela lírica de materia arcádica, poblada de personajes cultos disfrazados de pastores. Aunque no dio a conocer la varias veces anunciada segunda parte, jamás renunció a su proyecto. El Quijote posee numerosos episodios de corte pastoril. El más notable corresponde a la historia de Marcela y Grisóstomo, en la Primera Parte. Marcela rechaza a sus pretendientes y decide vivir como pastora: "Yo nací libre, y para poder vivir libre escogí la soledad de los campos: los árboles de estas montañas son mi compañía; las claras aguas de estos arroyos, mis espejos; con los árboles y con las aguas comunico mis pensamientos y hermosura." (126) Los jóvenes enamorados se hacen pastores para solicitarla. Entre ellos, Grisóstomo, quien muere de amor por Marcela.

A su vez, la historia de Leandra concluye con cierto aire de humor con sus pretendientes viviendo el amor frustrado en la soledad de la vida pastoril bajo el arquetipo de la Arcadia. La Segunda Parte de El Quijote incluye un episodio en el cual los ricos pobladores de una aldea han decidido entretenerse siguiendo las pautas de la tradición mítica y literaria de la Arcadia: "En una aldea que está hasta dos leguas de aquí, donde hay mucha gente principal y muchos hidalgos y ricos, entre muchos amigos y parientes se concertó que con sus hijos, mujeres y hijas, vecinos, amigos y parientes nos viniésemos a holgar a este sitio, que es uno de los más agradables de todos esos contornos, formando entre todos una nueva y pastoril Arcadia, vistiéndonos las doncellas de zagalas y los mancebos de pastores. Traemos estudiadas dos églogas, una del famoso poeta Garcilaso, y otra del excelentísimo Camoes, en su misma lengua portuguesa, las cuales hasta ahora no hemos representado. [...] Si gustáis, señor, de ser nuestro huésped, seréis agasajado liberal y cortésmente; 
porque, por ahora, en este sitio no ha de entrar la pesadumbre ni la melancolía”. (991) La precisión de que las églogas mencionadas no habían sido escenificadas declara que el juego pastoril es un acto frecuente en la vida social de los personajes. Para estos, además, fingir la Arcadia implica disfrutar de un momento de alegría, fuera de las preocupaciones cotidianas.

Condenado a suspender por un año sus actividades como caballero andante, don Quijote imagina consagrar este lapso a vivir a imitación de la Arcadia en traje de pastor amante: "Yo me quejaré de ausencia; tú te alabarás de firme enamorado; el pastor Carrascón, de desdeñado; y el Cura Curiambro de lo que él más puede servirse, y, así, andará la cosa, que no haya más que desear". (1063)

Aunque su sueño de vida pastoril no se realiza, el programa narrativo es concebido con tal detalle y aceptado con tanta satisfacción y colaboración por casi todos los personajes convocados a participar que en realidad vemos al caballero, a Sancho, a su mujer e hija, al Cura, a Sansón Carrasco, al barbero Nicolás, metamorfoseados a lo pastoril y en plena acción. Esta hipotética aventura pastoral queda fuertemente inducida en el receptor real por la intensa experiencia de lectura caballeresca y pastoril que la novela le ha hecho vivir durante tantos capítulos. Don Quijote, "pastor por andar", (1098), tiene todas las posibilidades abiertas.

Las alusiones literarias y textuales significan formas de lectura o pistas de lectura, variaciones de lectura o usos de la lectura. Igualmente, la cita real o hipotética constituye un tipo de lectura. Veamos un caso de cita supuesta y, además, anticipada: "¿Quién duda, sino que en los venideros tiempos, cuando salga a luz la verdadera historia de mis famosos hechos, que el sabio que los escribiere no ponga, cuando llegue a contar esta mi primera salida tan de mañana, de esta manera?: "Apenas había el rubicundo Apolo tendido por la faz de la ancha y espaciosa tierra las doradas hebras de sus hermosos cabellos [...] cuando el famoso caballero don Quijote de la Mancha, 
dejando las ociosas plumas, subió sobre su famoso caballo Rocinante y comenzó a caminar por el antiguo y conocido campo de Montiel" (35) Aquí el personaje imagina un texto sobre sí mismo y lee en voz alta sus propias acciones transtextualizadas.

En El Quijote, cada personaje lector o auditor de literatura participa en un proceso de anagnórisis o reconocimiento, por medio del cual descubre su verdadera identidad como centro generador de fabulaciones. Los distintos momentos en que los personajes centrales de la novela se encuentran con sus lectores dan lugar a una inmediata intervención del mecanismo de anagnórisis. Los receptores identifican apariencia, gesto y discurso con las imágenes de sus lecturas y trasladan su simpatía de lectores hacia las recién reconocidas figuras de sus héroes. Una forma peculiar de anagnórisis nos remite al lector externo de la novela de Cervantes, quien reconoce las asociaciones, parodias, alusiones, referencias, imitaciones, traslados, duplicaciones.

Además de libros de caballería y novelas pastoriles, los personajes demuestran ser receptores agudos de cuentos, teatro y poesía. Ellos son sensibles tanto a la manera de ejecución oral de una historia como al contenido de lo narrado. Después de escuchar el relato del Cautivo, don Fernando dice "Por cierto, señor capitán, el modo con que habéis contado este extraño suceso ha sido tal, que iguala a la novedad y extrañeza del mismo caso: Todo es peregrino y raro y lleno de accidentes que maravillan y suspenden a quien los oye; y es de tal manera el gusto que hemos recibido en escuchalle, que aunque nos hallara el día de mañana entretenidos en el mismo cuento, holgáramos que de nuevo se comenzara”. (439)

Uno de los resultados pragmáticos de la lectura yace en su capacidad para provocar la escritura. El manuscrito en que se encuentra la continuación del relato de la pelea entre don Quijote y el Vizcaíno presenta anotaciones marginales realizadas por algún otro lector que incluyen un dibujo iluminado sobre la escena. En el capítulo 24 de la Segunda 
Parte, Cide Hamete se comporta como lector y re-escritor de su propio manuscrito cuando anota marginalmente ciertos reparos al episodio de la cueva de Montesinos: "No me puedo dar a entender ni me puedo persuadir que al valeroso don Quijote le pasase puntualmente todo lo que en el antecedente capítulo queda escrito. [...] y si esta aventura parece apócrifa, yo no tengo la culpa, y, así, sin afirmarla por falsa o verdadera, la escribo. Tú, lector, pues eres prudente, juzga lo que te pareciere, que yo no debo ni puedo más". (734) El canónigo que encuentra al Cura y acompañantes llevando enjaulado a don Quijote, pese a que manifiesta haber leído solamente el comienzo de numerosos libros de caballerías, demuestra ser un profundo lector y conocedor del género. Baste recordar la divertida y prolija llamada de atención que le hace a don Quijote: "¿Y cómo es posible que haya entendimiento humano que se dé a entender que ha habido en el mundo aquella infinidad de Amadises y aquella turbamulta de tanto famoso caballero, tanto Emperador de Trapisonda, tanto Felixmarte de Hircania, tanto palafrén, tanta doncella andante, tantas sierpes, tantos endriagos, tantos gigantes, tantas inauditas aventuras, tanto género de encantamientos, tantas batallas, tantos desaforados encuentros, tanta bizarría de trajes, tantas princesas enamoradas, tantos escuderos condes, tantos enanos graciosos, tanto billete, tanto requiebro, tantas mujeres valientes y, finalmente, tantos y tan disparatados casos como los libros de caballerías contienen?" (503) No obstante que el canónigo desestima dichos libros porque no calzan con la moral cristiana y con los criterios estéticos clasicistas, sí les reconoce una virtud y es la de abrir la posibilidad para el lucimiento personal a través del más amplio desenvolvimiento de la escritura: "Porque la escritura desatada de estos libros da lugar a que el autor pueda mostrase épico, lírico, trágico, cómico, con todas aquellas partes que encierran en sí las dulcísimas y agradables ciencias de la poesía y de la oratoria: que la épica tan bien puede escribirse en prosa como en verso". (492) Lo que está describiendo el canónigo es nada menos que la naturaleza multigenérica y poli discursiva de la novela en general aplicada a los libros de caballerías. Al reconocer que 
la novela puede mezclar prosa y verso, establece la doble conexión de la novela con la épica, en consecuencia, escribir novelas implica una cierta dignidad concedida por su filiación con el género heroico. Así se explica que el contacto con la lectura de libros de caballerías haya producido en el canónigo el estímulo para la escritura: "Yo, a lo menos -replicó el canónigo-, he tenido cierta tentación de hacer un libro de caballerías, guardando en él todos los puntos que he significado; y si he de confesar la verdad, tengo escritas más de cien hojas". (493)

Para don Quijote el arte vence a la naturaleza. (510) Lo que él busca y halla en sus lecturas es la admiración, el gusto, la maravilla, que no encuentra en la naturaleza. Superar a la naturaleza supone, igualmente, que la lectura significa proscribir la melancolía y recuperar la salud: "lea estos libros, y verá cómo le destierran la melancolía que tuviere y le mejoran la condición, si acaso la tiene mala". (511) La lectura como antídoto de la melancolía recibe el testimonio de los practicantes de la nueva Arcadia, en donde "no ha de entrar la pesadumbre ni la melancolía", o de don Antonio Moreno, quien llega al extremo de defender la locura de don Quijote por "el gusto que da con sus desvaríos", y por sus gracias y las de Sancho, "que cualquiera de ellas puede volver a alegrar a la misma melancolía" (1050)

El episodio de Leandra enamorada de un soldado fanfarrón es una secuencia paralela al efecto que cualquier lectura literaria desencadena en los personajes. Leandra cae seducida por las apariencias de la ficción que promueve Vicente de la Roca: "Enamorola el oropel de sus vistosos trajes; encantáronla sus romances, que de cada uno que componía daba veinte traslados; llegaron a sus oídos las hazañas que él de sí mismo había referido [...]”" (518)

La forma en que la lectura es tratada en El Quijote depende de una categoría mayor de la cultura del barroco, la cual consiste en el concepto. Para el período, el concepto es un 
proceso asociativo entre objetos de toda índole, concretos o abstractos, reales o imaginados, mediante el cual el sujeto creador expresa su ingenio y su capacidad combinatoria. Fundamentalmente, se trata de un sistema de correlaciones que no depende de enlaces reales o naturales entre los objetos, sino de enlaces inventados. En realidad, un concepto es una metáfora, por lo tanto lo que está en juego en el barroco es un pensamiento puramente metafórico. En El Quijote la lectura es un tipo de concepto y, en tanto tal, depende de las invenciones del pensamiento metafórico cervantino. Son estas múltiples metaforizaciones acerca de la lectura las que la novela registra. Principalmente, tienen que ver con las clases de reacción que la lectura produce en los lectores. Naturalmente, en la novela la locura es un concepto en sí mismo, con sus propios enlaces y correlatos metafóricos, pero desde el punto de vista de la lectura es una forma de realización de un caso específico de concepto en torno a esta. Un tipo de asociación conceptual establece los vínculos entre lectura y locura como reacción exclusiva del protagonista. De aquí, a su vez, la poderosa cadena de conceptos acerca de las modalidades en que dicha reacción se concreta en los actos y discursos del personaje. La lectura, en cambio, es una actividad que el protagonista comparte con todos los demás personajes. Es cierto que algunas reacciones ante la lectura están muy próximas a la locura de don Quijote, como las de los duques. Sobre el particular, Cide Hamete dice que "tiene para sí ser tan locos los burladores como los burlados y que no estaban los duques dos dedos de parecer tontos, pues tanto ahínco ponían en burlarse de dos tontos". (1077) En estos casos, los matices en torno a la locura son formas de conceptos que tienen como eje la lectura.

Como concepto para el desenvolvimiento del ingenio la lectura alcanza su fórmula metafórica mas compleja cuando en la Segunda Parte de El Quijote, caballero y escudero intervienen como narradores, receptores y comentaristas de sus propias aventuras. Una forma de recepción auditiva de relatos en la Segunda Parte tiene que ver con el hecho de que 
don Quijote y Sancho cuentan sus aventuras ante el público que los acoge como invitados y que recibe con el mayor gusto sus historias. Justamente, haberse enterado por boca de Sansón Carrasco de su lectura del libro en que andan publicados sus hechos, provoca en Sancho y en don Quijote el deseo de volver a la acción en una tercera salida. Nótese la influencia que por vía indirecta tiene la lectura a través de la intermediación del lector Carrasco.

El encuentro con los duques da lugar a una extensa relación de acontecimientos festivos y burlescos, basados en el conocimiento que tienen del libro en que se consignan las actividades de don Quijote y Sancho: "[La duquesa y el duque] por haber leído la primera parte de esta historia y haber entendido por ella el disparatado humor de don Quijote, con grandísimo gusto y con deseo de conocerle le atendían, con prosupuesto de seguirle el humor y conceder con él en cuanto les dijese, tratándole como a caballero andante los días que con ellos se detuviese, con todas las ceremonias acostumbradas en los libros de caballerías, que ellos habían leído, y aun les eran muy aficionados". (781)

Los juegos propuestos por los duques en su castillo, ejecutados con riqueza y eficiencia por sus servidores, ampliados, además, por iniciativa de estos, señalan hasta qué punto los libros de caballerías son conocidos por un amplio sector de personajes de diferentes niveles sociales. En razón de este conocimiento difundido y compartido, no es mucho el esfuerzo que tienen que hacer los duques para lograr que la imaginación mimética de su personal ponga en acción las correspondientes lecturas hasta el grado de sorprender y maravillar con sus incansables maquinaciones a él y a su pareja. Los duques, lectores de numerosos libros de caballerías y de la historia publicada de don Quijote y Sancho, son expuestos principalmente como lectores de las parodias ejecutadas día y noche bajo su dirección o inventadas oficiosamente por sus criados. Así es como se señala que la duquesa lee la intervención final de Altisidora: "Quedó la 
duquesa admirada de la desenvoltura de Altisidora, que aunque la tenía por atrevida, graciosa y desenvuelta, no en grado que se atreviera a semejantes desenvolturas; y como no estaba advertida de esta burla, creció más su admiración". (983) En todo el prolongado periodo narrativo dedicado al encuentro con los duques, un sector notable de las operaciones de lectura se aplica a las cartas de Sancho, su mujer, don Quijote y la duquesa. Todas ellas son leídas en público y en voz alta para el disfrute de los asistentes.

Las relaciones entre literatura y fiesta definen la detallada elaboración del aparato de diversión que, a costa de don Quijote y su escudero, los habitantes del castillo han puesto a rodar. Esta secuencia de la novela constituye una apoteosis de la lectura y muestra a Cervantes como un artista del análisis de uus efectos que genera.

Más adelante, durante el encuentro con los entusiastas pobladores que representan la Arcadia, nuevamente se produce la coincidencia entre personajes y lectores. Dice una de las jóvenes que ha descubierto a don Quijote: “¿Ves este señor que tenemos delante? Pues hágote saber que es el más valiente y el más enamorado y el más comedido que tiene el mundo, si no es que nos miente y nos engaña una historia que de sus hazañas anda impresa y yo he leído". (992) Al invitar a participar en sus fiestas a don Quijote y a Sancho, los arcádicos establecen una fusión entre lo pastoril y lo caballeresco, nada inusual en el plano literario dentro del género de los libros de caballerías. La casualidad ha puesto en mano de los pobladores la forma de incrementar la ficción con más ficción: "Juntáronse en aquel sitio más de treinta personas, todas bizarramente de pastores y pastoras vestidas, y en un instante quedaron enteradas de quiénes eran don Quijote y su escudero, de que no poco contento recibieron, porque ya tenían de él noticia por su historia. Acudieron a las tiendas, hallaron las mesas puestas, ricas, abundantes y limpias; honraron a don Quijote dándole el primer lugar en ellas; mirábanle todos y admirábanse de verle". (992-993) 
Una variante de la lectura de los actos de don Quijote realizada en el interior de la novela es la que corresponde al texto de un supuesto autor aragonés, publicado como segunda parte de El Quijote. El encuentro con lectores de esta edición de Avellaneda, que al mismo tiempo son degustadores de la Primera Parte, plantea la discusión en torno a la inautenticidad del citado impreso y al correspondiente elogio de la Primera Parte. Don Quijote se niega a leer el libro por considerarlo mentiroso y necio. Como una manera de denunciar públicamente la falsedad de esta obra decide no ir a Zaragoza, como tenía previsto, sino a Barcelona, contradiciendo una de las aventuras que, según le informaban, constaba en el relato del aragonés: "no pondré los pies en Zaragoza y así sacaré a la plaza del mundo la mentira de ese historiador moderno, y echarán de ver las gentes cómo yo no soy el don Quijote que él dice". (1003-1004)

Don Alvaro Tarfe, personaje del libro de Avellaneda, se encuentra con don Quijote y es convencido por éste de firmar una declaración ante alcalde en la que hace constar "cómo no conocía a don Quijote de la Mancha, que asimismo estaba allí presente, y que no era aquel que andaba impreso en una historia intitulada Segunda parte de don Quijote de la Mancha, compuesta por un tal de Avellaneda, natural de Tordesillas". (1092) A manera de una curiosa antianagnórisis, don Alvaro queda declarado y convencido de su propia inexistencia: "vuelvo a decir y me afirmo que no he visto lo que he visto, ni ha pasado por mí lo que ha pasado". (1092)

La novela tematiza la lectura, esto es, hace de la lectura una meditación por momentos seria y, la mayoría de las veces, burlona e irónica. Por otro lado, la lectura es, asimismo, la forma constitutiva de la novela. En esta, las acciones reales o fingidas, los relatos interpolados, los personajes, las tertulias, el paisaje, los discursos, las cartas, los manuscritos, los ademanes, hallan su razón de ser en la lectura por su génesis, estructura, intención y destino. 
Desde sus inicios, la forma educada de leer un texto escrito ha planteado algunas de las siguientes operaciones: subrayar o resaltar partes del texto, realizar notas al margen o aparte, hacer comentarios y juicios valorativos, plantear dudas, interrumpir la lectura para continuar en otro momento, señalizar o marcar el libro, dar un paseo, beber o comer algo, alternar lecturas de diversos textos, buscar datos en otros libros, ir a comprar nuevos libros o solicitarlos en préstamo si la información que se requiere no consta en la biblioteca personal, incluir lecturas de distracción a manera de descanso, etc. (Prieto 1999: 323; Navarro 2003: 243 ss.)

Quisiera mostrar un ejemplo, quizás algo alejado ideológicamente del universo de El Quijote -aunque de esto no estoy tan seguro-que puede ilustrar lo que podemos llamar lectura idiosincrática. Nicolás Machiavelo en carta del 10 de diciembre de 1513 dirigida a Francisco Vettori, describe uno de sus días típicos: "Abandonado el bosque, me voy a una fuente, y de ahí a un terreno donde tengo tendidas mis redes para pájaros. Llevo un libro conmigo, Dante o Petrarca o alguno de esos poetas menores, como Tibulo, Ovidio y otros: leo sus pasiones amorosas y sus amores, me acuerdo de los míos. y me deleito un buen rato en esos pensamientos. Me traslado después a la vera del camino de la hostería, hablo con los que pasan, les pido noticias de sus pueblos, oigo diversas cosas y noto diversas fantasías de los hombres. [...] Cuando llega la noche, regreso a casa y entro en mi escritorio, y en el umbral me quito la ropa cotidiana, llena de fango y de mugre, me visto paños reales y curiales, y apropiadamente revestido entro en las antiguas cortes de los antiguos hombres donde, recibido por ellos amorosamente, me nutro de ese alimento que solo es mío, y que yo nací para él: donde no me avergüenzo de hablar con ellos y preguntarles por la razón de sus acciones, y ellos por su humanidad me responden; y no siento por cuatro horas de tiempo molestia alguna, olvido todo afán, no temo a la pobreza, no me asusta la muerte: todo me transfiero a ellos. Y como dice Dante que no hay ciencia sin el retener lo que se ha entendido, he anotado todo aquello 
de que por la conversación con ellos he hecho capital [...]" (Maquiavelo 1990: 135-138; Prieto 1999: 331)

Cervantes reproduce la dinámica típica de su estilo de leer textos escritos en la manera de distribuir, interrumpir e interpolar sus múltiples relatos orales; en la búsqueda de manuscritos que completen su suspendida historia; en la alternancia de relatos graves con relatos divertidos; en las dudas y los comentarios e interrogaciones que los lectores y auditores plantean a sus narradores; en los distintos puntos de vista que es necesario atender para llegar a una cabal comprensión de lo leído.

Como formulación homóloga de un esquema de conducta lectora como el que hemos resumido, podemos tomar de El Quijote la seriación e interpolación sufrida por el relato acerca de Cardenio y Lucinda. Contado en la Primera parte en los capítulos 23, 24 y 27, con interrupción en 25 y 26, es ampliado por Dorotea en 28, extendido e interrumpido en 29, avanza en 35 y es completado por Fernando en 36. Durante los capítulos 33 a 35 ha sucedido el relato del curioso impertinente, suspendido en 35, por el episodio de don Quijote y su batalla con los cueros de vino, para finalizar luego en este mismo capítulo.

Para concluir, propongo la consideración siguiente. El señor Miguel de Cervantes Saavedra nos invita a leer su novela siguiendo el hilo de una trayectoria que reproduce el ciclo de su manera idiosincrática de leer como hombre educado de su tiempo.

\section{BIBLIOGRAFÍA}

CASTILLO GÓMEZ, Antonio

2003

"Del Donoso y grande escrutinio". La lectura áurea entre la norma y la transgresión". En: Castillo Gómez, Antonio, ed. Libro y lectura en 
la península ibérica y América. Siglos XIII a XVIII. Salamanca: Junta de Castilla y León, 107-128.

CASTRO, Américo

1967 Hacia Cervantes. Madrid: Taurus.

CERVANTES, Miguel de

2004

Don Quijote de la Mancha. San Pablo (Brasil): Real Academia Española, Asociación de Academias de la Lengua Española. Edición del IV Centenario.

CHEVALIER, Maxime

1976

Lectura y lectores en España en los siglos XVI y XVII. Madrid: Turner.

CHARTIER, Roger

2000

El orden de los libros. Lectores, autores, bibliotecas en Europa entre los siglos XIV y XVIII. Barcelona: Gedisa.

FRENK, Margit

1997

Entre la voz y el silencio. Madrid: Centro de Estudios Cervantinos.

FUENTES, Carlos

1976

Don Quixote, or the critique of reading. Austin: Institute of Latin American Studies.

HUTCHEON, Linda

2000

A theory of parody. The Teachings of TwentyCentury Art Forms. Urbana and Chicago: University of Illinois Press.

HUTCHINSON, Steven

1992

Cervantine Journeys. Madison: The University of Wisconsin Press. 
LIDA, María Rosa

1962

La originalidad artística de La Celestina. Buenos Aires: Eudeba.

MAQUIAVELO, Nicolás

1990

Epistolario. 1512-1527. México: FCE.

MARTÍNEZ BONATI, Félix

1995

El Quijote y la poética de la novela. Alcalá de Henares: Centro de Estudios Cervantinos.

NAVARRO BONILLA, Diego

2003

"Las huellas de la lectura: marcas y anotaciones manuscritas en impresos de los siglos XVI a XVIII". En: Castillo Gómez, Antonio, ed. Libro y lectura en la península ibérica y América. Siglos XIII a XVIII. Salamanca: Junta de Castilla y León, 243-287.

PRIETO BERNABÉ, José Manuel

1999 "Prácticas de la lectura erudita en los siglos XVI y XVII". En: Castillo, Antonio, comp. Escribir y leer en el siglo de Cervantes. Barcelona: Gedisa, 313-343.

ROJAS, Fernando de 1991

La Celestina o Tragicomedia de Calisto y Melibea. Ed. de Peter E. Rusell. Madrid: Castalia. 